\title{
Bioconversion of Heavy Hydrocarbon Cuts Containing High Amounts of Resins by Microbial Consortia
}

\author{
Ghollami $\mathbf{M}^{1 *}$, Roayaei $\mathbf{M}^{1}$, Ghavipanjeh $\mathrm{F}^{2}$ and Rasekh B $^{3}$ \\ ${ }^{1}$ Biology Department, Shahid Chamran University, Ahwaz, Iran \\ ${ }^{2}$ Environment Group, Energy Department, Materials and Energy Research Center, Alborz, Iran
}

${ }^{3}$ Microbiology and Biotechnology Group, Research Institute of Petroleum Industry, Tehran, Iran

\begin{abstract}
Microbial conversion of petroleum resins existing in a heavy fraction of crude oil was investigated by native isolated consortia. The heavy oil fraction was taken from an end cut of distillation tower of Abadan refinery in Iran. Several Soil samples were taken from different oil contaminated sites of Abadan oil refinery in Khuzestan province. Seven bacterial consortia were then prepared by enrichment method and were examined for their ability to convert resins. Amongst them, consortium AB6 reduced $37.3 \%$ of resins while, aliphatic and aromatic compounds increased by $86.8 \%$ and $6.7 \%$, respectively. Three pure cultures were isolated from consortium AB6 which were identified as Serratia sp., Raoultella sp. and Ochrobactrum sp.
\end{abstract}

Keywords: Biological conversion; Resins; Serratia; Raoultella; Ochrobactrum

\section{Introduction}

Quality Improvement of crude oils has been one of the important problems in the recent 60 years. There are some chemical and physical methods for crude oil upgrading. But, due to high cost of the current oil processes together with their safety and environmental problems, attention to affordable and environmentally acceptable methods has gained significant importance [1,2]. In this regard, biotechnology as well as special ability of microorganisms for production of a wide range of biochemical materials has been an important technique in overcoming the defects of the other methods $[3,4]$.

Crude oil is a mixture of hydrocarbons containing hydrogen, carbon and lesser amounts of oxygen, sulphur and nitrogen plus some trace metals such as vanadium, nickel, copper and iron [5]. The hydrocarbons can be divided into aliphatic or saturates (including paraffins, isoparaffins and cycloparaffins), aromatics, resins and asphaltenes. Short chain paraffins are more degradable substrates for microorganisms compared with long chain paraffins, isoparaffins, cycloparaffins, aromatics, resins and asphaltenes. Resins and asphaltenes contain several hetroatoms per molecules and typically account for $30-60 \%$ of the total sulphur, $70-90 \%$ of total nitrogen and $80-90 \%$ of the total vanadium and nickel present in a crude oil $[6,7]$. Resins are large molecules containing polar groups with molecular weights substantially lower than those of asphaltenes. Their percentage in heavy oil fractions is higher than that of asphaltenes which is more in bitumen.

Resins and asphaltenes are less biodegradable and insufficient literatures are presented in this field [8]. Venkateswaran et al. [9] found a consortium consisted of pseudomonas sp and several un-named strains, which could degrade $35 \%$ of resins fractionated from crude oil, presenting the first results on biological degradation of resins as the authors claimed. In 2006, Ghavipanjeh et al. [10] investigated the biological conversion of a heavy hydrocarbon cut named as Isomax feed (a heavy end of vacuum distillation column) by mixed cultures. Their results showed a reduction of more than $10 \%$ of the resin fraction of the feed [10]. Heavy fractions of crude oil and distillation residues contain more amounts of resins and asphaltenes [11]. However, there is a trend towards the use of heavier feedstock, which requires additional processes based on the destruction of heavy petroleum compounds and lead to an increase in the portion of light fractions in feedstock [12].

Middle East region makes up only 1\% of Earth's surface. However, it contains $65.7 \%$ of the world's oil content. Iran is the first oil-rich country in this region with production capacity of 4 million barrels per day of crude oil and diesel fuel [13]. Khuzestan province contains massive oil and gas reservoirs and so is the most important oil region in Iran. However, most of the crude oils of the region contain a high level of resins. This makes process difficulties, clogging of transportation pipelines and hard environmental deterioration problems when spilled out.

Different reports during recent decades have shown that microbial consortia are more effective on degradation and conversion of hydrocarbons, compared with individual strains $[9,14,15]$. In this research, different soil samples were taken in order to investigate the effect of native consortia on bioconversion of petroleum resins. This could lead to biological upgrading of heavy petroleum fractions and help in removal of environmental oil spills. Resin Compounds are adhesive hard solids that precipitate in the bottom of distillation tower or in oil wells leading to oil recovery decreases. This paper investigates the biological conversion of resin using native mixed cultures and identifying the types of the bacteria involved in the process.

\section{Materials and Methods}

\section{Samples and feed}

Seven soil samples were collected from oil contaminated sites of Abadan oil refinery in Khuzestan province and named as AB1, AB2,

*Corresponding author: Mahboobeh Ghollami, Biology Department, Shahid Chamran University, Ahwaz, Iran, Tel: 021- 44350761; Fax: 021- 44216661; E-mail: m.ghollami@yahoo.com

Received March 16, 2012; Accepted April 19, 2013; Published April 26, 2013

Citation: Ghollami M, Roayaei M, Ghavipanjeh F, Rasekh B (2013) Bioconversion of Heavy Hydrocarbon Cuts Containing High Amounts of Resins by Microbial Consortia. J Pet Environ Biotechnol 4: 139. doi:10.4172/2157-7463.1000139

Copyright: @ 2013 Ghollami M, et al. This is an open-access article distributed under the terms of the Creative Commons Attribution License, which permits unrestricted use, distribution, and reproduction in any medium, provided the original author and source are credited. 
$\mathrm{AB} 3, \mathrm{AB} 4, \mathrm{AB} 5, \mathrm{AB} 6$ and $\mathrm{AB} 7 . \mathrm{A}$ Heavy oil fraction containing a high percentage of resin compounds was taken from an end cut of distillation tower of Abadan oil refinery and used as the hydrocarbon feed for enrichment of microorganisms. The characteristics of the heavy end feed are shown in Table 1.

\section{Enrichment and bacterial growth}

Batch cultures were conducted in $250 \mathrm{ml}$ flasks containing 5\% (w/v) hydrocarbon feed, $10 \mathrm{ml}$ of supernatant prepared from each soil sample $(10 \%(\mathrm{w} / \mathrm{v})$ soil in distilled water) and a mineral salt medium (MSM) consisting of $\mathrm{K}_{2} \mathrm{HPO}_{4} 2.75 \mathrm{~g} / \mathrm{l}, \mathrm{KH}_{2} \mathrm{PO}_{4} 2.25 \mathrm{~g} / \mathrm{l},\left(\mathrm{NH}_{4}\right)_{2} \mathrm{SO}_{4} 1$ $\mathrm{g} / \mathrm{l}, \mathrm{MgSO}_{4} .7 \mathrm{H}_{2} \mathrm{O} 0.2 \mathrm{~g} / \mathrm{l}, \mathrm{NaCl} 0.1 \mathrm{~g} / \mathrm{l}$ and $\mathrm{FeCl}_{3} \cdot 6 \mathrm{H}_{2} \mathrm{O} 0.02 \mathrm{~g} / \mathrm{l}$. The $\mathrm{pH}$ of the medium was adjusted at $6.8 \pm 2$. The flasks were kept in a shaker incubator at $30^{\circ} \mathrm{C}$ and $150 \mathrm{rpm}$ for 10 days. The inoculation procedure from the previous flasks was repeated three times for preparation of the enrichment cultures. The enrichment cultures were named as $A B 1$, $\mathrm{AB} 2, \mathrm{AB} 3, \mathrm{AB} 4, \mathrm{Ab} 5, \mathrm{AB} 6$ and $\mathrm{AB} 7$.

Duplicate batch cultures were conducted from the last enrichment cultures in contact with the heavy oil feed as the same conditions as above, in order to investigate the biological conversion of the feed. Also, a flask was prepared without microorganisms as the control sample. All the flasks were incubated at $30^{\circ} \mathrm{C}$ and $150 \mathrm{rpm}$ for 10 days. The optical densities of the aqueous phases of the cultures were measured along time in order to investigate the growth of the microorganisms. At the end of the incubation, the samples were used for further investigations as follows.

\section{Sample selection and bacteria isolation}

Best sample selection was made upon bacterial growth and visual observations of the organic phases compared to that of the control sample. Strains of the consortia were isolated considering their bioconversion capacity. Selected isolates were purified by pour plate method and kept in refrigerator for further experiments.

\section{Hydrocarbon analysis}

After bio-treatment of the feed, the oil phases were separated from the aqueous phases in order to analyze the bioconversion of the organics especially the resins by the enriched cultures [16]. In this method, normal pentene was used as the solvent of the organic phase because of its ability to solve the organic phase and different molecular weight with water and its evaporation point is also low. So, it could be easily separated from the organic phase. $15 \mathrm{ml}$ of pentane was added to sample in a decanter funnel and shake vigorously and then let to settle for 45 minute. The oil and aqueous phases were then separated. The procedure was repeated twice. The extracted organic phases were then dehydrated by passing through dehydrated $\mathrm{MgSO}_{4}$ and evaporated in a water bath for the separation of the solvent. The separated bio-treated organic phases plus the control sample were divided into four defined

\begin{tabular}{|c|c|}
\hline Parameter & Value \\
\hline Initial boiling point $\left({ }^{\circ} \mathrm{C}\right)$ & 384 \\
\hline Final Boiling Point $\left({ }^{\circ} \mathrm{C}\right)$ & 575 \\
\hline Sulfur $(\mathrm{ppm})$ & 18863 \\
\hline Carbon $(\mathrm{Wt} \%)$ & 65 \\
Iron $(\mathrm{ppm})$ & 3.5 \\
\hline Nickel $(\mathrm{ppm})$ & 5.2 \\
\hline Resin $(\%)$ & 48.95 \\
\hline Asphaltene $(\%)$ & 7.37 \\
\hline Viscosity $\left(\mathrm{g} / \mathrm{cm}^{3}\right)$ & 0.597 \\
\hline
\end{tabular}

Table 1: The characteristics of the heavy end feed. fractions: Saturates (aliphatics), Aromatics, Resins and Asphaltenes (SARA fractions). The asphaltenes fraction was determined by precipitation with n-pentane according to ASTM method D-893. The remained organic phases after asphaltene separation were conveyed on adsorption chromatography to separate aliphatic, aromatic and resin fractions of the oils. The procedure was made according to ASTM D2549 with some modifications $[10,17,18]$. This was achieved by using n-pentane solvent (for elution of aliphatics), diethyl ether (for elution of aromatics) and, chloroform and ethanol (for elution of resins). An optical test of TLC paper under UV light was done at the same time for identification of hydrocarbon fractions during elution. A spot of the eluted on TLC paper would turn to purple under UV light by the aromatics while making no color for the aliphatics. The fractions were then evaporated to remove the solvents and weighed. The aliphatic, aromatic and resin fractions of the bio-treated oils were compared to that of the control sample.

\section{Resin analysis}

In order to further inspection of the effect of native cultures on the resin contents of the heavy end feed, the separated resin fractions were divided into soft resins and hard resins. The resin fractions were dissolved in $15 \mathrm{ml}$ of a mixture of isobutyl alcohol and cyclohexane $(80: 20)$ in which the hard resins were precipitated. The soft resins were then precipitated in $12 \mathrm{ml}$ isobutyl alcohol [6].

\section{GC-MASS analysis}

The separated bio-treated organic phases of the selected consortia as well as the control sample were analyzed for the compositional changes using gas chromatography mass spectroscopy (GC-MASS). Here, Agilent instrument model 7890A equipped with a mass selective detector model $5975 \mathrm{C}$ and column, BP-5 $(50 \mathrm{~m} \times 0.25 \mathrm{~mm})$ was used with initial temperature $50^{\circ} \mathrm{C}$, final temperature $280^{\circ} \mathrm{C}$, ramp rate $5^{\circ} \mathrm{C}$ per min and helium as the carrier gas at $20 \mathrm{ml} / \mathrm{min}$.

\section{Identification of the isolates}

The pure cultures isolated from the selected consortium were identified by several morphological, biochemical and phylogenic methods [13,19-21]. The biochemical tests were include Gram stain, Methyl Red test, Voges-Proskauer test, Citrate test, Acid production (TSI), Urease, Indole production, Motility, producing hydrogen sulfide, and lysine decarboxylase. The molecular identification of bacteria was done by amplification of gene $16 \mathrm{~s}$ rRNA by universal primers. The sequences (5'-3') of the forward and reverse primers were: AAGAGTTTGATCATGGCTCAG and AGGAGGTGATCCAACCGCA, respectively [22]. The PCR program for amplification of gene was $94^{\circ} \mathrm{C}$ the temperature of denaturation for $1 \mathrm{~min}, 62^{\circ} \mathrm{C}$ the temperature of bonding primers for 40 second and 150 second at $72^{\circ} \mathrm{C}$. The number of amplification cycles was 30 [23]. After that the DNA sequence data were analyzed using BLAST-N (Local alignment search tool) [24].

\section{Results and Discussion}

\section{Enrichment and bacterial growth}

After 3 times sub-culturing of the samples at $30^{\circ} \mathrm{C}$ and $150 \mathrm{rpm}$, the visual observations were made on the bio-treated samples compared to the control sample. Amongst the seven samples, four samples had imposed obvious changes on the organic phases, while causing turbidity in the aqueous phases. These samples included AB4, AB5, 
Citation: Ghollami M, Roayaei M, Ghavipanjeh F, Rasekh B (2013) Bioconversion of Heavy Hydrocarbon Cuts Containing High Amounts of Resins by Microbial Consortia. J Pet Environ Biotechnol 4: 139. doi:10.4172/2157-7463.1000139

AB6, and AB7 Figure 1 shows the growth curves of the two selected consortia (AB4 and $\mathrm{AB} 6)$ in the presence of the heavy end cuts.

\section{Bacterial isolation}

The isolated bacteria of the selected consortia were: 4 strains from $\mathrm{AB} 4,2$ strains from $\mathrm{AB} 5,3$ strains from $\mathrm{AB} 6$ and 3 strains from $\mathrm{AB} 7$.

\section{Hydrocarbons analysis}

The results of the gravimetric measurement of SARA fractions of the selected bio-treated samples are shown in Table 2. According to the table, the aliphatic fractions of the all bio-treated samples are increased compared with the control sample. Also, the aromatic fractions of $\mathrm{AB} 4$ and AB6 are increased compared with the control sample. The resin fractions of all bio-treated samples are decreased compared with the control sample but are more significant in AB4 and AB6. This emphasizes the ability of consortia $\mathrm{AB} 4$ and $\mathrm{AB} 6$ in declining the resin contents of the heavy end cuts as we expected. Also, the increase of aliphatics and aromatics are also a good sign. Considering the resin compounds reduction, we can say the enhancement in aliphatics and aromatics fractions amount that are lighter compounds than resins is probably due to conversion and changes of resin compounds.

\section{Resin analysis}

The resin compounds fractionated from the control and the superior bio-treated samples (ABR4 and ABR6) were separated into soft and hard resins. The results are shown in Table 3, which can be seen that the hard resins are entirely removed after bio-treatment of the feed. Though, $14.4 \%$ of total resins of the control sample are the hard resins. This indicates that larger molecules are converted to lighter ones via biological process.

\section{GC-MASS analysis}

The GC-MASS analyses of the mixtures of aliphatic and aromatic fractions of AB6 and the control sample are shown in Figure 1. As reveals from the figures, the differences between the chromatograms are not clearly obvious due to high complexity of the compounds. Some of the compounds are shown in the figures, as could be seen the peaks heights are changes.

The analysis of the GC-MASS digital library data revealed some differences as indicated in Table 4. The table shows that some compounds are disappeared from the control sample, while some others are appeared in the bio-treated samples. For example, toluene

INITIAL.
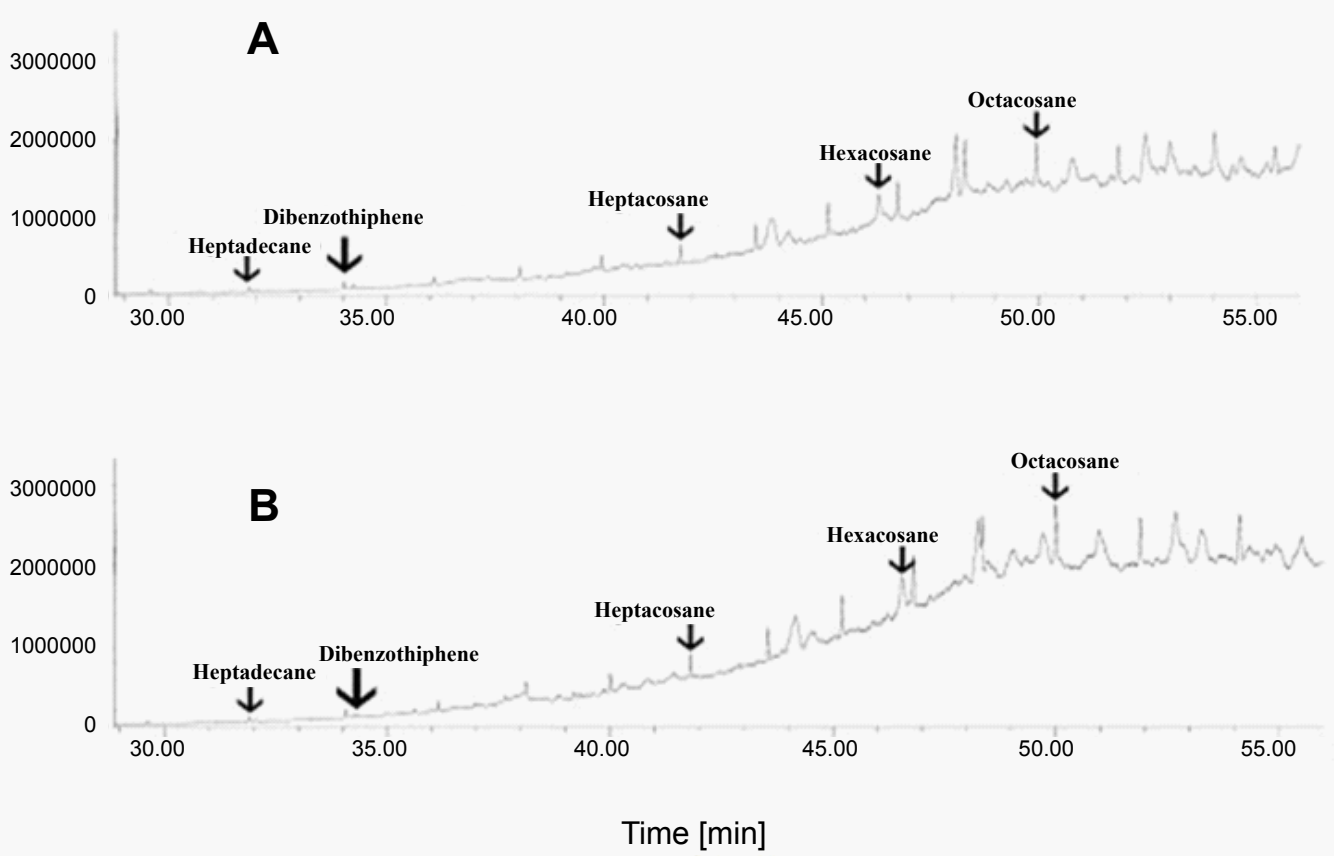

Figure 1: A: GC-MASS chromatogram of the mixture of aliphatic and aromatic fractions of the control sample. B: GC-MASS chromatogram of the mixture of aliphatic and aromatic fractions of $\mathrm{AB} 6$ sample.

\begin{tabular}{|c|c|c|c|c|c|c|c|}
\hline \multirow[b]{3}{*}{ Sample name } & \multicolumn{7}{|c|}{ Hydrocarbon fractions } \\
\hline & \multicolumn{2}{|c|}{ Saturates } & \multicolumn{2}{|c|}{ Aromatics } & \multicolumn{2}{|c|}{ Resins } & \multirow{2}{*}{$\begin{array}{l}\text { Asphaltenes } \\
\% \text { in sample }\end{array}$} \\
\hline & $\%$ in sample & $\%$ of changes & $\%$ in sample & $\%$ of changes & $\%$ in sample & $\%$ of changes & \\
\hline AB4 & 26.85 & 49.75 & 30.09 & 18.09 & 34.58 & -27.93 & 8.48 \\
\hline AB5 & 26.6 & 48.35 & 19.59 & -23.12 & 45.21 & -5.77 & 8.60 \\
\hline AB6 & 33.51 & 86.89 & 27.20 & 6.75 & 30.07 & -37.3 & 8.51 \\
\hline$A B 7$ & 23.99 & 33.8 & 23.15 & -9.14 & 44.41 & -7.44 & 8.45 \\
\hline Control & 17.93 & - & 25.48 & - & 47.98 & - & 8.61 \\
\hline
\end{tabular}

Table 2: The amounts of SARA fractions in the biotreated oil samples and the percent of changes compare to the control. 
Citation: Ghollami M, Roayaei M, Ghavipanjeh F, Rasekh B (2013) Bioconversion of Heavy Hydrocarbon Cuts Containing High Amounts of Resins by Microbial Consortia. J Pet Environ Biotechnol 4: 139. doi:10.4172/2157-7463.1000139

\begin{tabular}{|c|c|c|}
\hline Sample name & Hard resin (\%) & Soft resin (\%) \\
\hline Control & 14.4 & 85.6 \\
\hline ABR4 & 0 & 100 \\
\hline ABR6 & 0 & 100 \\
\hline
\end{tabular}

Table 3: The amounts of hard resins and soft resin of the resin fractions.

\begin{tabular}{|c|c|c|c|}
\hline Time & Compounds & $\begin{array}{l}\text { \% in control } \\
\text { sample }\end{array}$ & $\begin{array}{l}\% \text { in treated } \\
\text { sample }\end{array}$ \\
\hline 4.014 & 1-propanol, 2- methyl & & 0.22 \\
\hline 4.025 & $\begin{array}{l}\text { Propene, 2-methyl-3- } \\
\text { Propoxy }\end{array}$ & $\overline{9} .59$ & - \\
\hline 9.856 & Pentadecane & 0.95 & 0.54 \\
\hline $\begin{array}{l}9.879 \\
28.630\end{array}$ & Toluene & - & $\begin{array}{l}0.54 \\
0.20\end{array}$ \\
\hline 28.933 & Dibromotetradecane-1-01acetate & $\overline{0} .26$ & \\
\hline 36.028 & Heptacosane, 1-chloro- & & 0.35 \\
\hline 36.097 & Dibenzothiphene, 4-methyl- & $\overline{0} .54$ & - \\
\hline 36.795 & $\begin{array}{l}\text { Imidazo(4,5-f)quinolone,2-amino-3-methyl- } \\
\text { Anthracene, 9,butyl tetradecahydro }\end{array}$ & 2.68 & - \\
\hline 36.961 & Octadecane & - & $\begin{array}{l}0.34 \\
0.37\end{array}$ \\
\hline 39.856 & Cyclotriacontane & - & \\
\hline 39.953 & Phenanthrene, 3,6-dimethyl & $\overline{1} .25$ & - \\
\hline 41.756 & Heptacosane, 1-chloro- & 1.35 & \\
\hline 41.807 & Triacontane & & 3.04 \\
\hline 45.149 & Hexacosane & $\overline{2} .86$ & \\
\hline 45.206 & Octacosane & & 5.63 \\
\hline $\begin{array}{l}52.439 \\
52.679\end{array}$ & $\begin{array}{l}\text { 9.19-cyclolanost-23-ene-3, 25-diol, } \\
\text { 3-acetate }\end{array}$ & 15.00 & $\overline{1} 2.32$ \\
\hline
\end{tabular}

Table 4: The compositional changes of the mixture of aliphatic and aromatic fractions of the sample treated by AB6 compared with that of control, according to GC-MASS Digital library.

\begin{tabular}{|c|c|c|c|}
\hline \multicolumn{4}{|c|}{ Strains } \\
\hline Characteristics & AB6S1 & AB6S2 & AB6S3 \\
\hline Morphology & Bacilli & Cocobacill & Cocobacill \\
\hline Gram stain & - & - & - \\
\hline Urea hydrolysis & - & - & - \\
\hline Citrate & + & + & + \\
\hline MR & + & + & - \\
\hline VP & - & - & + \\
\hline TSI & Alk-Alk & Alk-Alk & Acid-Acid \\
\hline Lysine decarboxylase & + & + & + \\
\hline Indole & - & + & - \\
\hline Hydrogen sulfide & - & - & - \\
\hline Motility & + & - & - \\
\hline
\end{tabular}

Table 5: Biochemical characteristics of the isolated strains of AB6 consortium.

and tetradecane did not exist in the control but appeared in the biotreated sample by AB6. Also, the amounts of short chain alkanes were decreased compared to the control. However, the amounts of alcoholic compounds, alkanes and polycyclic compounds were increased compared to the control.

\section{Identification of the isolates}

Three pure cultures were isolated from consortium AB6 as the best native consortium on conversion of resins. The biochemical characteristics of the isolated organisms were shown in Table 5. The strain AB6S1 produced red pigments on nutrient agar plates with a weak elevation after 24 hours of incubation. They were rod shaped, aerobic, gram negative and motile. They were also citrate positive, decarboxylases lysine, indole negative and hydrogen sulfide negative. Morphologically, the colonies of AB6S2 were isolated were pigmented in shades of green and cells were also round and small. The bacteria were citrate positive, decarboxylases lysine, indole positive, hydrogen sulfide negative, non- motile, aerobic, and gram negative. Another isolate, $\mathrm{AB} 6 \mathrm{~S} 3$ produced colonies, which were cream, circular, flat and rough edges. Microscopically, they were seen as gram negative and non-motile. The bacteria were citrate positive, indole negative, hydrogen sulfide negative and decarboxylases lysine. The results revealed the genus of the bacteria.

\section{Conclusions}

This research investigated the biological conversion of a heavy end cut containing high amounts of resins by means of native bacterial consortia. Seven consortia were adapted from which consortium AB6 had the highest activity on the feed. The analytical results on the bio-treated oil showed that the amounts of aliphatics and aromatics were increased by $86.9 \%$ and $6.7 \%$, respectively. Also, the amounts of resins were decreased by $37.3 \%$. This could be due to elimination of heteroatoms in molecules of resins by the bacteria that beaks the large molecule. Also, further analysis of the resins content of the feed showed that all the hard resins were eliminated after bio-treatment and the remained resins were all in the class of soft resins. This reinforces the idea of cleavage of hard resins into smaller molecules by bacteria, which again could be due to elimination of heteroatoms from the molecules.

The isolates of consortium AB6 were identified as Serratia sp., strain PBCC12 (Gen bank Accession No, JN566121.1), Raoultella sp., strain PBCC13 (Gen bank Accession No, JN566122.1) and strain PBCC14 (Gen bank Accession No, JN566123.1) Ochrobactrum sp.

\section{Acknowledgements}

This work was supported by Materials and Energy Research Center under M.Sc. Thesis. The authors are so thankful to Mr. Shahab Aldin Zarekhafri for him numerous helps during the whole states of experiments.

\section{References}

1. Simanzhenkov V, Idem R (2003) Crude Oil Chemistry. CRC Press Newyork USA.

2. Mashreghi M, Marialigeti K (2005) Characterization of Bacteria Degrading Petroleum Derivatives Isolated from Contaminated Soil and Water. Journal of Sciences, Islamic Republic of Iran 16: 317-320.

3. Das N, Chandran P (2011) Microbial degradation of petroleum hydrocarbon contaminants: an overview. Biotechnol Res Int.

4. Obire O, Nwaubeta O (2001) BioDegradation of Refined Petroleum Hydrocarbons in Soil. J Appl Sci Environ Mgt 5: 43-46.

5. Grishchenkov VG, Townsend RT, McDonald TJ, Autenrieth RL, Bonner JS et al. (2000) Degradation of petroleum hydrocarbons by facultative anaerobic bacteria under aerobic and anaerobic conditions. Process Biochem 35: 889896

6. Speight JG (2002) Handbook of Petroleum Product Analysis. John Wiley \& Sons, Inc. USA.

7. Gailiute I, Grigiskis S, Zekaite G, Cipinyte V (2011) Selection of Microbes and Conditions That Induced Bio-Cracking of Branched Hydrocarbon Squalane. Environment Technology Resources 1: 46-52.

8. Van Hamme JD, Singh A, Ward OP (2003) Recent Advances in Petroleum Microbiology. Microbiol Mol Biol Rev 67: 503-549.

9. Venkateswaran K, Hoaki T, Kato M, Maruyama T (1995) Microbial degradation of resins fractionated from Arabian light crude oil. Can J Microbiol 41: 418-424.

10. Ghavipanjeh F, Pazouki M, Shayegan J, Hosseinnia A (2006) Evaluation of microorganism utilization in cracking of ISOMAX feed (project phase 1, fina report). National Iranian Oil Refining and Distribution Company (NIORDC).

11. Bernard O, Michel M (2005) Petroleum Microbiology. American Society for Microbiology.

12. Grin'ko AA, Golovko AK (2011) Fractionation of resins and asphaltenes and investigation of their composition and structure using heavy oil from the Usa field as an example. Petrol Chem 51: 192-202. 
Citation: Ghollami M, Roayaei M, Ghavipanjeh F, Rasekh B (2013) Bioconversion of Heavy Hydrocarbon Cuts Containing High Amounts of Resins by Microbial Consortia. J Pet Environ Biotechnol 4: 139. doi:10.4172/2157-7463.1000139

13. Amiriyan A, Mazaheri Assadi M, Saggadian VA, Noohi A (2004) Bioemulsan Production by Iranian Oil Reservoirs Microorganisms. Iranian J Env Health Sci Eng 1: 28-35.

14. Diaz-Ramirez IJ, Escalante-Espinosa E, Favela-Torres E, Gutierrez-Rojas M, Ramirez-Saad H (2008) Design of bacterial defined mixed cultures for biodegradation of specific crude oil fractions, using population dynamics analysis by DGGE. Int Biodeter Biodegr 62: 21-30.

15. Ghazali FM, Abdul Rahman RNZ, Salleh AB, Basri M (2004) Biodegradation of hydrocarbons in soil by microbial consortium. Int Biodeter Biodegr 54: 61-67.

16. Korda A, Santas P, Tenente A, Santas R (1997) Petroleum hydrocarbon bioremediation: sampling and analytical techniques, in situ treatments and commercial microorganisms currently used. Appl Microbiol Biotechnol 48: 677686.

17. Premuzic ET, Lin M Bohenek MS, Zhou WM (1999) Bioconversion Reactions in Asphaltenes and Heavy Crude Oils. Energy Fuels 13: 297-304.
18. ASTM committee(1982) Annual Book of ASTM Standards. Part 46

19. Okoh $\mathrm{Al}$ (2006) Biodegradation alternative in the cleanup of petroleum hydrocarbon pollutants. Biotechnology and Molecular Biology Review 1: 38-50.

20. Mittal A, Singh P (2009) Isolation of hydrocarbon degrading bacteria from soils contaminated with crude oil spills. Indian J Exp Biol 47: 760-765.

21. Malatova K (2005) Isolation and Characterization of Hydrocarbon Degrading Bacteria from Environmental Habitats in Western New York State. Rocheste Institute of Technology Newyork USA

22. Weisburg WG, Barns SM, Pelletier DA, Lane DJ (1991) 16 S ribosomal DNA amplification for phylogenetic study. J Bacteriol 173: 697-703.

23. Benson HJ, Brown AE (2006) Benson's Microbiological Applications: Laboratory Manual in General Microbiology. McGraw-Hill Higher Education USA.

24. Altschul SF, Gish W, Miller W, Myers EW, Lipman DJ (1990) Basic loca alignment search tool. J Mol Biol 215: 403-410. 